\title{
Identification and assessment of the driving forces for the use of urban green parks and their accessibility in Colombo, Sri Lanka, through analytical hierarchical processing
}

\author{
P.G.R.N. Indika Pussella, ${ }^{1-3}$ Lin $\mathrm{Li}^{1,2}$ \\ ${ }^{1}$ School of Resources and Environmental Science, Wuhan University, China; ${ }^{2}$ Collaborative Innovation \\ Center of Geo Spatial Technology, Wuhan University, China; ${ }^{3}$ Department of Remote Sensing and GIS, \\ Faculty of Geomatics, Sabaragamuwa University, Sri Lanka
}

\begin{abstract}
Urban green parks perform a remarkable role for the physical, social and psychological wellbeing of the urban public by providing space for relaxation and recreation, directly influencing public health through mitigation of the urban heat impact, noise reduction and moderation of air and water pollution. An indicator-based approach on analytical hierarchical processing was used to identify and assess the driving forces for the utilization of urban green parks and their accessibility. Eight indicators: location, topography and geography, facility and services, safety and security, social and culture, ecology, demography, and weather and climate (further divided into 50 factors) were used in the study. Data were collected through a questionnaire survey in which 887 regular park users participated. A standardized study design was imple-
\end{abstract}

Correspondence: P.G.R.N. Indika Pussella, School of Resources and Environmental Science, 129, Luoyu Road, Wuhan 430079, Wuhan University, China

Tel.: +94714990964.

E-mail: indikapussella@yahoo.com

Key words: Green; Parks; Analytical hierarchical processing; Urban; Health; Public; Sri Lanka.

Acknowledgements: the authors would like to thank the participants of the questionnaire survey.

Contributions: the authors contributed equally.

Conflict of interest: the authors declare no potential conflict of interest.

See online Appendix for additional materials.

Received for publication: 12 September 2018.

Revision received: 13 November 2018.

Accepted for publication: 6 January 2019.

(C) Copyright P.G.R.N.I. Pussella and L. Li, 2019

Licensee PAGEPress, Italy

Geospatial Health 2019; 14:738

doi:10.4081/gh.2019.738

This article is distributed under the terms of the Creative Commons Attribution Noncommercial License (CC BY-NC 4.0) which permits any noncommercial use, distribution, and reproduction in any medium, provided the original author(s) and source are credited. mented to study and assess four urban green parks in the Colombo metropolitan district, Sri Lanka. The study identified park facilities and services as well as safety and security measures maintained by the park as the key factors of appeal, while location, ecology, topography and geography, including weather and climate, had a lower relative influence when selecting a park for recreation. Social, cultural and demographic factors appeared to be of the least interest. The study recommends park managers to assess their parks using this model to enhance the characteristics found to be the most important. It further suggests developing models also for other park types by considering which factors would have the highest relative influence in providing a better service for the regular park user.

\section{Introduction}

As a result of rapid population growth and transition from rural to economical and industrial areas of development, urban expansion is widespread, specially, in the metropolitan areas of developing countries (Shi et al., 2009; Abubakr and Pradhan, 2016). This can be taken as a positive initiative (Fan, 1999), since people can afford more opportunities and resources to improve the standard of living in cities than they can in a village (Poyil and Misra, 2015). Urban expansion is, however, often associated with unplanned, uncoordinated and uncontrolled change (Noor and Rosni, 2013) and the intensified pressure on resources and natural environment influence the city space negatively (Dadras et al., 2015), particularly when the cities expand into the adjoining rural areas (Hegazy and Kaloop, 2015). From an economic perspective, population growth and rise in income lead to increased land values and residents therefore seek less expensive options in suburban and ex-urban areas (Pendall, 1999). As a result, urban areas and suburbs experience a remarkable reduction of size and quality of green spaces, eventually leading to an ecological imbalance.

Green spaces play a vital role in maintaining human physical, social and psychological wellbeing (De Ridder, 2003; Berg et al., 2010, Arabi et al., 2014) by mitigating the urban heat island effect as well as air and water pollution (Jennings et al., 2016) and also noise. There is a close relationship between public health and the quality of green spaces (Berg et al., 2010) and urban parks perform a big role for recuperation. They also play a role for the local economy by generating revenues for municipal councils and increase property values by providing an aesthetic and pleasant environment. The general public uses urban green parks for various purposes, such as rest, leisure or physical training. However, 
papers by Gilbert (1989) and Uy and Nakagoshi (2008) both mention that physical parameters such as size, shape and diversity within parks influence green-space functions. Availability of, and accessibility to, green parks are dimensions that can be used to assess the ecological sustainability of a city and spatial standards have been introduced by various organizations. United Nations, European Union and World Health Organization suggest that 30 $\mathrm{m}^{2}, 26 \mathrm{~m}^{2}$ and $9 \mathrm{~m}^{2}$, respectively, be kept as green space per capita in a city (Khalil, 2014), while the National Recreation and Park Association in the United States says that at least $0.41 \mathrm{~km}^{2}$ park space should be allocated per 1,000 people (Nicholls, 2001). The Six Acre Standard defined by the UK National Playing Fields Association argues that $0.24 \mathrm{~km}^{2}$ space is needed to be maintained as an open area per 1,000 residents (Nicholls, 2001). Herzele and Wiedemann (2003) stated that urban parks should be located within a distance of $400 \mathrm{~m}$ ( 5 min walking distance) from people's residences. Handley et al. (2003) mention that residents should live in areas no further than $300 \mathrm{~m}$ away from natural green spaces of at least $0.02 \mathrm{~km}^{2}$ in size and that at least $0.01 \mathrm{~km}^{2}$ of natural space per 1,000 urban residents should be provided.

The pattern with respect to the use of, and accessibility to, urban parks has been considered taking different aspects into account. Herzele and Wiedemann (2003) used an indicator-based geographical information systems (GIS) approach to study the urban public's interest in parks in Belgium, while Nicholls (2001) prioritised accessibility and equity leading to a management system for leisure. Cho et al. (2008) attempted to identify the amenity value of open spaces with Ordinary Least Squares and regression analysis considering quantitative parameters (size and proximity) and qualitative parameters (spatial configuration). The usage pattern of urban parks by different ethnic categories has been analyzed (Comber et al., 2008) and a GIS-based regression analysis applied to understand the spatial distribution of, and accessibility to, urban parks in Switzerland (Germann-Chiari and Seeland, 2004). Meanwhile, Rosa (2014) has proposed an indicator-based approach with simple distance and proximity components to evaluate the accessibility of the general public to urban parks. Based on the results of network analysis, it can be argued the vital role of availability of data and resources in modelling the accessibility (Rosa, 2014).

Regrettably, as pointed out by Wolch et al. (2014), city parks are not always distributed consistently and equitably. In areas where low- income people live, the number of parks is inadequate with limited facilities, while the situation is the opposite where rich people live. Wolch et al. (2014) stated that this well-known, worldwide scenario is an environmental injustice. Generally, accessibility is totally dependent on various technical, social and cultural factors. According to Rosa (2014), accessibility has to do with environmental justice and that it represents a flexible concept with different interests and different public categories. The appeal of green parks is governed by proximity (or access by transport), availability of facilities, safety and security, quality of space, social interactions and privacy (Masnavi, 2000; Moirongo, 2002; Herzele and Wiedemann, 2003; Abubakar and Aina, 2006). Therefore, the usage of parks need to be promoted by guaranteeing space for sports, walking paths, wooded areas and play areas for children (McCormack et al., 2010). Kaczynski and Henderson (2007) emphasize that the distance from residency to park is inversely proportionate to its regular usage. Further, according to McCormack et al. (2010), use and accessibility is significantly dependent on the general physical and mental health situation of the public. Therefore, anybody involved with park planning and management must consider and learn to understand the proper use of parks by the general public as well as what the limits of accessibility are.

Compared with other countries, the use of urban parks by the general public in Sri Lanka is commonly limited due to lowincome levels, busy life, few available park facilities and petty crime. The land tenure system practiced plays an important role which has led to the tradition of living in separate family houses, even in Colombo and suburbs, where they maintain small residential gardens of their own. However, there is currently a trend to change the land tenure pattern by introducing tall buildings with many apartments in order to get more land for commercial and industrial activities. As a result, the use of parks is increasing and it is suggested to maintain urban parks at accessible distances. However, the present scenario of available parks in the city needs to be analyzed. The present study was initiated to introduce an indicator-based approach that could identify and assess the driving forces for usage and accessibility of urban parks leading to a park management system ultimately supporting the physical and mental health of urban residents. The specific objectives of the study were to analyze the physical, social, cultural and environmental parameters of urban parks with the ulterior motive of finding out how to grant all city residents access to areas for relaxation, rest and leisure as well as safety and security.

\section{Materials and Methods}

\section{Study site}

Colombo City is the main industrial, commercial and economical hub of the country and its metropolitan area is responsible for more than $80 \%$ of industrial output and $50 \%$ of the Gross Domestic Product of the country (Subasinghe et al., 2016). The residential population of Colombo was 0.55 million in 2012 (Department of Census and Statistics of Sri Lanka, 2012) with a growth rate of $1.1 \%$ according to world development indicators of the World Bank in 2017 with a floating population of approximately 0.5 million (Department of Census and Statistics of Sri Lanka, 2012). The city area covers $37.29 \mathrm{~km}^{2}$ in size.

The locations of available parks in Colombo City and suburbs were identified using existing maps and digital data layers at the scale 1:10,000 produced by the Survey Department of Sri Lanka, the national mapping agency. Four main, well-known urban parks: Viharamahadevi Park in the Colombo metropolitan area, Diyatha Uyana amusement park in Baththaramulla, Bellanvila urban park in Boralesgamuwa and Seethawaka Wet Zone botanical garden in Labugama were selected for the case study. Among them, Seethawaka Park is situated just outside Colombo main City, while Diyatha Uyana and Bellanvila parks are situated closer to the city centre (Figure 1).

\section{Data collection}

Two types of data were used, locations and attributes, where the latter represent the characteristics of the selected urban parks. Information on the parks was collected from existing maps, Google Earth images, individual site plans, field investigations and discussions with park users and park administrations. The site plans were available as large-scale surveyed plans with contours 
under the operation of the Urban Development Authority of Sri Lanka, the governmental organization for urban planning and administration. Important buildings and places nearby such as government and private offices, famous temples and other places were identified using these maps and images. Past records on temperature, humidity, air pollution and noise were obtained from the Meteorological Department of Sri Lanka, while the Disaster Management Centre of Sri Lanka was contacted for data on weather patterns of the study areas and disaster occurrences. The characteristics of the four parks selected for the study are summarized in Table 1.

\section{Methodological approach}

The relative importance, generally referred to as weights of indicators and factors utilized to assess the use of, and ease of accessibility to, urban parks, was determined by the analytical hierarchical process (AHP) technique, which consists of three steps: development of the hierarchical tree structure, pair-wise comparison analysis and development of a pair-wise matrix (Nonis et al., 2007). Data related to the use of the parks were collected through a questionnaire survey in which 887 regular park users participated. In selecting participants for the survey at different time intervals, firstly, their gender, age, education level, occupation and the time of usage were ascertained in order to get unbiased results (Table A1 in the Appendix).

The use of, and accessibility to, the parks were modelled based on the eight indicators shown in Figure 2, which also includes different types of factors used to define these indicators. A semi-structured questionnaire was designed to guide the participants to deliver their opinions according to the hierarchical model. To that end, a pair-wise matrix based on the 9-degree Likert scale (Caklovic and Radas, 2014) was prepared considering two criteria at a time comparing their relative importance as shown in Table A2 (in the Appendix). The indicators were arranged as a multilevel decision structure, in which the views of the participants were used to arrange the indicators according to priority. The relative importance of each pair of indicators was determined as seen in Figure 3 with Level 2 of the tree structure developed further producing 50 separate factors that were given rank values according to the views expressed in the survey, in turn producing the final influence of each indicator (Table 2)

The relative influence of factors and ranks shown in Table 2 determined the value of each indicator, the computation of which is shown in Figure 4 using the topography and geography indicator as an example.

Separate indicator values were calculated from the individual influences of indicators as shown in Eq. 1. The Use and Accessibility indices of the parks were determined from the values of indicators and their relative importance using Eq. 2.

Indicator value $=\sum$ Value of the factor $\times$ Relative Importance

Use and Accessibility Index $=\sum$ Indicator value $\times$ Relative Importance

Eq. 2

The pair-wise comparison matrices were produced to determine the relative importance of the factors for each indicator was based on the results obtained from the questionnaires using the minority rule where the minority abides by the majority. For example, the facility and services indicator (consisting of 14 factors) was obtained by the matrix shown in Table 3 (the numbers of the
A

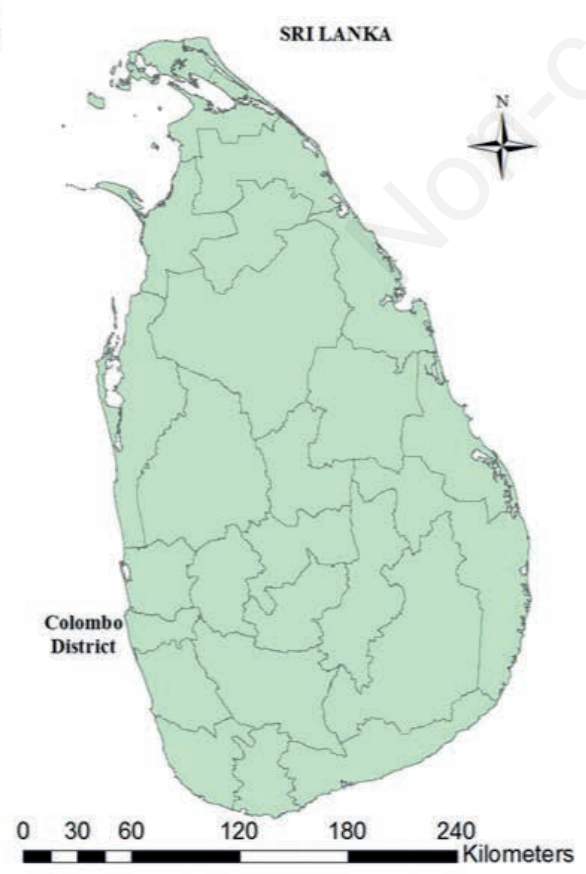

B

SELECTED URBAN GREEN PARKS

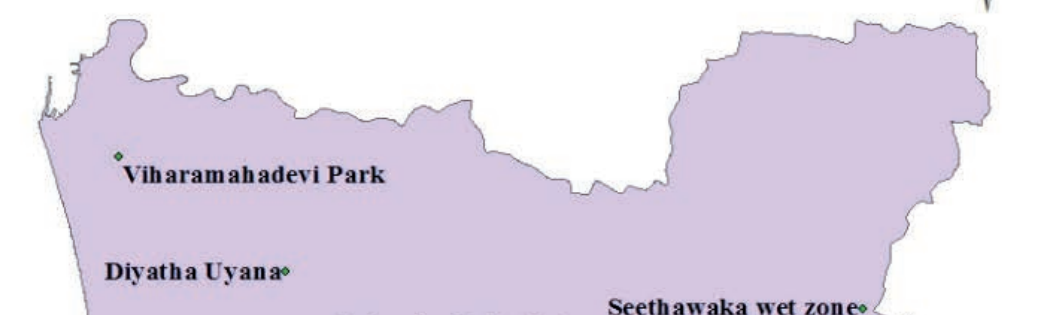

Bellanvila park

Colombo District

Seethawaka wet zoneo

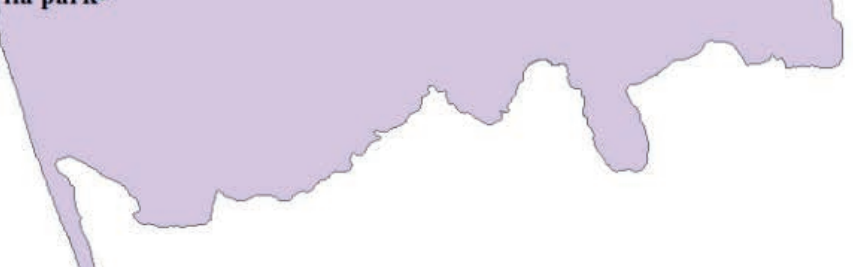

$0 \quad 3.75 \quad 7.5$

15
30

Figure 1. Colombo City (A) shown with its place in Sri Lanka (B). 
Table 1. Characteristics of the four parks studied.

\begin{tabular}{|c|c|c|c|c|c|}
\hline Factor & Unit & Viharamahadevi Park & Diyatha Uyana & Bellanvila Park & Seethawaka Park \\
\hline 1. Sport activities & No. & 12 & 17 & 18 & 6 \\
\hline 2. Walking paths & $\mathrm{m}$ & 2300 & 1800 & 1600 & 2500 \\
\hline 3. Bicycle paths & $\mathrm{m}$ & 400 & 600 & 1500 & 200 \\
\hline 4. Toilets & No. & 12 & 10 & 8 & 8 \\
\hline 5. Water fountains & No. & 18 & 24 & 25 & 12 \\
\hline 6. Rubbish bins & No. & 25 & 40 & 43 & 24 \\
\hline 7. Tuck shops & No. & 4 & 29 & 23 & 3 \\
\hline 8. Picnic tables and chairs & No. & 54 & 148 & 120 & 20 \\
\hline 9. Light posts & No. & 12 & 54 & 48 & 18 \\
\hline 10. Parking spaces & No. & 120 & 400 & 240 & 50 \\
\hline 11. Information boards & No. & 21 & 43 & 40 & 16 \\
\hline 12. Cleanliness/maintenance & No. & Not bad & Very good & Very good & Good \\
\hline 13. Maintenance workers & No. & 40 & 50 & 40 & 12 \\
\hline 14. Meeting areas & m2 & 1000 & 1200 & 800 & 800 \\
\hline 15. Entrance limitations & No. & 0 & 2 & 2 & 4 \\
\hline 16. Security officers & No. & 5 & 15 & 12 & 4 \\
\hline 17. Street children & No. & 100 & 0 & 0 & 0 \\
\hline 18. Park fencing & $\%$ & 0 & 25 & 35 & 75 \\
\hline 19. Violence events/week & No. & 10 & 1 & 2 & 0 \\
\hline 20. Harassments/week & No. & 4 & 0 & 1 & 0 \\
\hline 21. Park accidents & No. & 1 & 0 & 0 & 0 \\
\hline 22. Pets allowed & No. & No & Yes & No & No \\
\hline 23. Homeless dogs & No. & 20 & 0 & 0 & 2 \\
\hline 24. Thefts per week & No. & 3 & 1 & 0 & 1 \\
\hline 25. Important places & No. & 14 & 12 & 8 & 2 \\
\hline 26. Distance by main road & $\mathrm{m}$ & 5 & 10 & 12 & 250 \\
\hline 27. Distance to park & Min. & 1 & 2 & 2 & 10 \\
\hline 28. Distance to next park & $\mathrm{km}$ & 5 & 5 & 8 & 25 \\
\hline 29. Public transportation & & Abundant & Abundant & Abundant & Rare \\
\hline 30. Distance to city centre & $\mathrm{km}$ & 0.1 & 0.5 & 0.5 & 12 \\
\hline 31. Topography (flat areas) & $\%$ & 100 & 100 & 100 & 50 \\
\hline 32. Size & km2 & 5 & 2 & 2 & 8 \\
\hline 33. Shape & & Broad & Broad & Broad & Broad \\
\hline 34. Daily average no. of visitors & No. & 200 & 600 & 400 & 14 \\
\hline 35. Average time spent in park & Hour & 1 & 2 & 2 & 3 \\
\hline 36. Shaded area & $\%$ & 40 & 20 & 15 & 75 \\
\hline 37. Water area & $\%$ & 5 & 30 & 15 & 25 \\
\hline 38. Wooded area & $\%$ & 0 & 20 & 5 & 45 \\
\hline 39. Noise level & $\mathrm{dB}$ & 65 & 60 & 60 & 5 \\
\hline 40. Air pollution $\left(\mathrm{SO}_{2}\right)$ & ppm & 35 & 34 & 36 & 8 \\
\hline 41. Air pollution $\left(\mathrm{NO}_{2}\right)$ & ppm & 45 & 42 & 23 & 6 \\
\hline 42. Biodiversity (animals) & No. & $<15$ & $15-30$ & $<25$ & $>60$ \\
\hline 43. Biodiversity (trees) & No. & $<50$ & $>100$ & $>100$ & $>200$ \\
\hline 44. Ethnic groups & & Equal & Equal & Equal & Biased \\
\hline 45. Gender & & Equal & Equal & Equal & Equal \\
\hline 46.Average annual temperature & ${ }^{\circ} \mathrm{C}$ & 28 & 27 & 27 & 25 \\
\hline 47. Rainy days & Day & 58 & 65 & 59 & 122 \\
\hline 48. Average rainfall & $\mathrm{mm}$ & 2000 & 2000 & 1800 & 2400 \\
\hline 49. Average rel. humidity-day & $\%$ & 85 & 75 & 75 & 50 \\
\hline 50. Disaster occurrence & & Not at all & Not at all & Yes & Yes \\
\hline
\end{tabular}




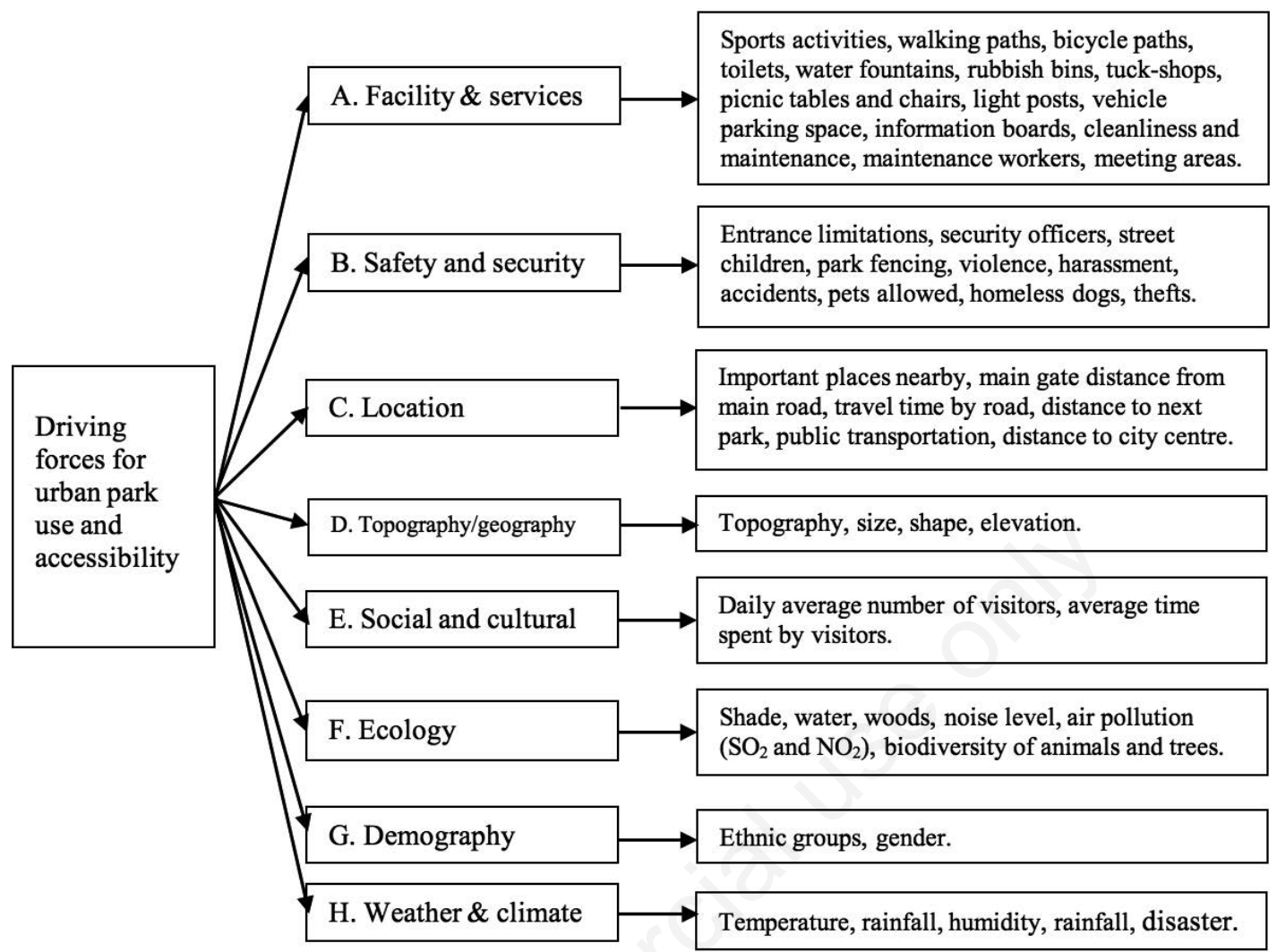

Figure 2. Hierarchical tree structure.

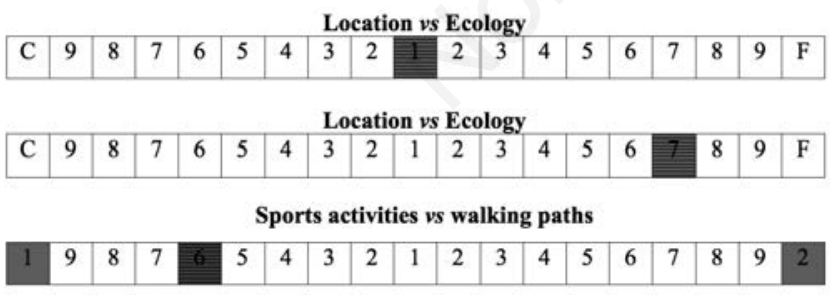

Figure 3. Examples of scoring. The first example indicates that the location indicator $(\mathrm{C})$ and the ecology indicator $(\mathrm{F})$ are equally important in the pair-wise comparison (score 1), while the second example indicates that the ecology indicator $(F)$ can be assumed to be much more important than the location indicator (C) by another participant (score 7). However, in the third example dealing with the determination of the relative importance of sports activities and walking paths under the facility and services indicator (A), a participant may feel that the importance of sports activities falls between clearly more important and much more important (Table A2 in the Appendix) than walking paths, he would then select 6 as the score in the pair-wise comparison. The rule saying that the minority should abide by the majority was used to prepare the final pair-wise comparison matrix.

\section{Calculation of the topography/geography indicator as an example}

\begin{tabular}{|c|c|c|}
\hline Factor & Value & Rank \\
\hline Topography & $60 \%$ flat & 4 \\
\hline Size & $7.5 \mathrm{~km}^{2}$ & 3 \\
\hline Shape & Broad & 5 \\
\hline
\end{tabular}

$$
T G=\frac{1.02 \times T+1.42 \times S i \times 0.56 \times S h}{1.02+1.42+0.56}=3.71
$$

Figure 4. Computation of indicator values. TG, topography/ geography indicator; $T$, value of the topography factor; $\mathrm{Si}$, value of the size factor; $\mathrm{Sh}$, value of the shape factor. 
factors are the same as those in Table 2). The normalized matrix shown in Table 4 for the facility and services indicator was obtained by dividing each cell value in Table 3 by its column sum. The sums across each row (shown in the last column to the right) were taken as the relative influence of each factor. The same methodology was used to determine the relative influence of all eight indicators used in this study.

By using the individual rank values and the relative importance of factor, the indicator values for each park under study were obtained (Table 5). This was done by first multiplying the rank of each factor with the relative influence of that factor (Tables 3 and 4). And then, the arithmetic sum of the multiplication was divided

Table 2. Rank values of the factors investigated.

\begin{tabular}{|c|c|c|c|c|c|c|c|c|}
\hline Indicator & Factor & Unit & 0 & 1 & $\begin{array}{c}\text { Rank value } \\
2\end{array}$ & 3 & 4 & 5 \\
\hline A. Facility and services & $\begin{array}{l}\text { 1. Sports activities } \\
\text { 2. Walking paths } \\
\text { 3. Bicycle paths } \\
\text { 4. Toilets } \\
\text { 5. Water fountains } \\
\text { 6. Rubbish bins } \\
\text { 7. Tuck shops } \\
\text { 8. Picnic tables and chairs } \\
\text { 9. Light posts } \\
\text { 10. Vehicle park space } \\
\text { 11. Information boards } \\
\text { 12. Cleanliness/maintenance } \\
\text { 13. Maintenance workers } \\
\text { 14. Meeting areas }\end{array}$ & $\begin{array}{l}\text { No. } \\
\mathrm{m} \\
\mathrm{m} \\
\text { No. } \\
\text { No. } \\
\text { No. } \\
\text { No. } \\
\text { No. } \\
\text { No. } \\
\text { No. } \\
\text { No. } \\
\text { Level } \\
\text { No. } \\
\mathrm{m}^{2}\end{array}$ & $\begin{array}{c}0 \\
0 \\
0 \\
0 \\
0 \\
0 \\
0 \\
0 \\
0 \\
0 \\
0 \\
\text { Very bad } \\
0 \\
0\end{array}$ & $\begin{array}{c}1-3 \\
100 \\
100 \\
1 \\
1 \\
2 \\
1 \\
<10 \\
<5 \\
<10 \\
<5 \\
\mathrm{Bad} \\
<5 \\
<100\end{array}$ & $\begin{array}{c}4-6 \\
101-300 \\
101-300 \\
2 \\
2-3 \\
3-5 \\
2 \\
11-20 \\
6-10 \\
11-20 \\
6-10 \\
\text { Neither/nor } \\
6-10 \\
101-500\end{array}$ & $\begin{array}{c}6-10 \\
301-500 \\
301-500 \\
3 \\
4-5 \\
6-10 \\
3 \\
21-50 \\
11-20 \\
21-50 \\
11-20 \\
\text { Moderate } \\
11-20 \\
501-1000\end{array}$ & $\begin{array}{c}10-15 \\
501-1000 \\
501-1000 \\
4 \\
5-10 \\
10-20 \\
4 \\
51-100 \\
21-50 \\
51-100 \\
21-50 \\
\text { Good } \\
21-50 \\
1001-2000\end{array}$ & $\begin{array}{c}>15 \\
>1000 \\
>1000 \\
>4 \\
>10 \\
>20 \\
>4 \\
>100 \\
>50 \\
>100 \\
>50 \\
\text { Very g0od } \\
>50 \\
>2001\end{array}$ \\
\hline B. Safety and security & $\begin{array}{l}\text { 15. Entrance limitations } \\
\text { 16. Security officers } \\
\text { 17. Street children } \\
\text { 18. Fencing around park } \\
\text { 19. Violence events/week } \\
\text { 20. Harassments/ week } \\
\text { 21. Accidents/week } \\
\text { 22. Pets allowed } \\
\text { 23. Homeless dogs } \\
\text { 24. Thefts per week }\end{array}$ & $\begin{array}{l}\text { No. } \\
\text { No. } \\
\text { No. } \\
\% \\
\text { No. } \\
\text { No. } \\
\text { No. } \\
\text { No. } \\
\text { No. } \\
\text { No. }\end{array}$ & $\begin{array}{c}>10 \\
0 \\
>20 \\
0 \\
>5 \\
>5 \\
>5 \\
\text { No } \\
>5 \\
>5\end{array}$ & $\begin{array}{c}10-9 \\
1 \\
20-16 \\
20 \\
5 \\
5 \\
5 \\
\text { NA } \\
5 \\
5\end{array}$ & $\begin{array}{c}8-6 \\
2-5 \\
15-11 \\
40 \\
4 \\
4 \\
4 \\
\mathrm{NA} \\
4 \\
4\end{array}$ & $\begin{array}{c}5-3 \\
6-10 \\
10-6 \\
60 \\
3 \\
3 \\
3 \\
\mathrm{NA} \\
3 \\
3\end{array}$ & $\begin{array}{c}2-1 \\
11-20 \\
5-1 \\
80 \\
2-1 \\
2-1 \\
2-1 \\
\text { NA } \\
2-1 \\
2-1\end{array}$ & $\begin{array}{c}0 \\
>20 \\
0 \\
100 \\
0 \\
0 \\
0 \\
\text { Yes } \\
0 \\
0\end{array}$ \\
\hline C. Location & $\begin{array}{l}\text { 25. Important places } \\
\text { 26. Main gate - Road gap } \\
\text { 27. Distance by main road } \\
\text { 28. Distance to next park } \\
\text { 29. Public transportation } \\
\text { 30. Distance to city centre }\end{array}$ & $\begin{array}{l}\text { No. } \\
\text { m } \\
\text { Min. } \\
\mathrm{km} \\
\mathrm{km}\end{array}$ & $\begin{array}{c}0 \\
>1000 \\
>60 \\
<5 \\
\text { No } \\
>20\end{array}$ & $\begin{array}{c}1 \\
751-1000 \\
30-60 \\
\\
\text { Very rare } \\
11-20\end{array}$ & $\begin{array}{c}2 \\
501-750 \\
20-30 \\
5-10 \\
6-10\end{array}$ & $\begin{array}{c}3 \\
251-500 \\
10-20 \\
11-20 \\
\text { Rare } \\
3-5\end{array}$ & $\begin{array}{c}4 \\
101-250 \\
5-10\end{array}$ & $\begin{array}{c}>4 \\
<100 \\
<5 \\
>20 \\
\text { Abundant } \\
<1\end{array}$ \\
\hline D. Topography/geography & $\begin{array}{l}\text { 31. Topography (flat area) } \\
\text { 32. Size } \\
\text { 33. Shape }\end{array}$ & $\begin{array}{c}\% \\
\mathrm{~km}^{2}\end{array}$ & & $\begin{array}{c}0-25 \\
<1 \\
\text { Narrow }\end{array}$ & $\begin{array}{l}26-50 \\
2-5\end{array}$ & $\begin{array}{l}100 \\
6-10\end{array}$ & $\begin{array}{l}51-75 \\
11-20\end{array}$ & $\begin{array}{c}50 \\
>20 \\
\text { Broad }\end{array}$ \\
\hline E. Social and cultural & $\begin{array}{l}\text { 34. Daily average of visits* } \\
\text { 35. Average time in the park }\end{array}$ & $\begin{array}{l}\text { No. } \\
\text { Hour }\end{array}$ & $<10$ or $>500$ & $\begin{array}{c}11-20 \text { or } 401-500 \\
\quad<1\end{array}$ & $\begin{array}{c}21-50 \text { or } 301-400 \\
1-2\end{array}$ & $\begin{array}{c}51-75 \text { or } 251-300 \\
2-3\end{array}$ & $\begin{array}{c}76-100 \text { or } 201-250 \\
3-4\end{array}$ & $\begin{array}{c}0101-200 \\
>4\end{array}$ \\
\hline F. Ecology & $\begin{array}{l}\text { 36. Shaded area } \\
\text { 37. Water area } \\
\text { 38. Wooded area } \\
\text { 39. Noise level } \\
\text { 40. Air pollution }\left(\mathrm{SO}_{2}\right) \\
\text { 41. Air pollution }\left(\mathrm{NO}_{2}\right) \\
\text { 42.Bio diversity (animals) } \\
\text { 43. Bio diversity (trees) }\end{array}$ & $\begin{array}{c}\% \\
\% \\
\% \\
\text { dB } \\
\text { ppm } \\
\text { ppm } \\
\text { No. } \\
\text { No. }\end{array}$ & $\begin{array}{l}0-5 \\
>60 \\
>30 \\
>30 \\
<10 \\
<10\end{array}$ & $\begin{array}{c}0-20 \\
0-20 \\
6-10 \\
56-60 \\
26-30 \\
26-30 \\
10-20 \\
10-20\end{array}$ & $\begin{array}{l}21-40 \\
21-30 \\
11-15 \\
51-55 \\
21-25 \\
21-25 \\
21-30 \\
21-30\end{array}$ & $\begin{array}{l}41-60 \\
31-40 \\
16-20 \\
46-50 \\
16-20 \\
16-20 \\
31-40 \\
31-40\end{array}$ & $\begin{array}{l}61-80 \\
41-50 \\
21-25 \\
40-45 \\
10-15 \\
10-15 \\
41-50 \\
41-50\end{array}$ & $\begin{array}{c}81-100 \\
51-100 \\
25-100 \\
<40 \\
<10 \\
<10 \\
>50 \\
>50\end{array}$ \\
\hline G. Demography & $\begin{array}{l}\text { 44. Ethnic groups } \\
\text { 45. Gender }\end{array}$ & $\begin{array}{l}\text { Bias } \\
\text { Bias }\end{array}$ & & $\begin{array}{l}\text { High } \\
\text { High }\end{array}$ & $\begin{array}{l}\text { Middle } \\
\text { Middle }\end{array}$ & $\begin{array}{l}\text { Moderate } \\
\text { Moderate }\end{array}$ & $\begin{array}{l}\text { Equal } \\
\text { Equal }\end{array}$ & $\begin{array}{l}\text { Very equal } \\
\text { Very equal }\end{array}$ \\
\hline H. Weather and climate & $\begin{array}{l}\text { 46. Average annual temp. } \\
\text { 47. Rainy days } \\
\text { 48. Average rainfall } \\
\text { 49. Average. rel. humidity-day } \\
\text { 50. Disaster occurrence }\end{array}$ & $\begin{array}{c}{ }^{\circ} \mathrm{C} \\
\text { Day } \\
\mathrm{mm} \\
\% \\
\text { Yes/no }\end{array}$ & $\begin{array}{l}>35 \\
>49 \\
>3000 \\
>80 \\
\text { Yes }\end{array}$ & $\begin{array}{c}35-32 \\
49-40 \\
3000-2501 \\
76-80 \\
\text { NA }\end{array}$ & $\begin{array}{c}31-29 \\
39-30 \\
2500-2001 \\
71-75 \\
\text { NA }\end{array}$ & $\begin{array}{c}28-26 \\
29-20 \\
2000-1501 \\
66-70 \\
\text { NA }\end{array}$ & $\begin{array}{c}25-23 \\
19-10 \\
1500-1001 \\
61-65 \\
\text { NA }\end{array}$ & $\begin{array}{c}<23 \\
<10 \\
<1000 \\
<60 \\
\text { Not at all }\end{array}$ \\
\hline
\end{tabular}

*There is a low limit which concerns people who avoid the park due to security reasons, and there is a high limit which concerns people who would not come to the park if it is too crowded, since they would then feel their privacy incroached. 
Table 3. Pair-wise matrix for the facility and services indicator.

\begin{tabular}{ccccccccccccccc} 
& 1 & 2 & 3 & 4 & 5 & 6 & 7 & 8 & 9 & 10 & 11 & 12 & 13 & 14 \\
1 & 1 & 1 & 2 & 1 & 1 & 7 & 9 & 6 & 5 & 7 & 9 & $1 / 5$ & 5 & 6 \\
2 & 1 & 1 & 1 & $1 / 7$ & $1 / 8$ & $1 / 4$ & 5 & 8 & $1 / 3$ & $1 / 5$ & 7 & $1 / 7$ & 3 & $1 / 4$ \\
\hline 3 & $1 / 2$ & 1 & 1 & $1 / 6$ & $1 / 5$ & $1 / 3$ & $1 / 2$ & $1 / 4$ & $1 / 3$ & $1 / 5$ & 6 & $1 / 5$ & 7 & 1 \\
4 & 1 & 7 & 6 & 1 & 1 & 4 & 3 & 5 & 7 & 5 & 9 & 1 & 9 & 8 \\
\hline 5 & 1 & 8 & 5 & 1 & 1 & 1 & 1 & 5 & 4 & 6 & 7 & $1 / 4$ & 6 & 9 \\
6 & $1 / 7$ & 4 & 3 & $1 / 4$ & 1 & 1 & 1 & 6 & 5 & 8 & 6 & 1 & 5 & $1 / 6$ \\
\hline 7 & $1 / 9$ & $1 / 5$ & 2 & $1 / 3$ & 1 & 1 & 1 & 7 & 5 & 5 & 6 & $1 / 5$ & 2 & 9 \\
8 & $1 / 6$ & $1 / 8$ & 4 & $1 / 5$ & $1 / 5$ & $1 / 6$ & $1 / 7$ & 1 & $1 / 4$ & $1 / 3$ & 4 & $1 / 6$ & 5 & 1 \\
\hline 9 & $1 / 5$ & 3 & 3 & $1 / 7$ & $1 / 4$ & $1 / 5$ & $1 / 5$ & 4 & 1 & 1 & 6 & $1 / 9$ & 3 & $1 / 7$ \\
10 & $1 / 7$ & 5 & 5 & $1 / 5$ & $1 / 6$ & $1 / 8$ & $1 / 5$ & 3 & 1 & 1 & $1 / 9$ & $1 / 6$ & 3 & $1 / 6$ \\
\hline 11 & $1 / 9$ & $1 / 7$ & $1 / 6$ & $1 / 9$ & $1 / 7$ & $1 / 6$ & $1 / 6$ & $1 / 4$ & $1 / 6$ & 9 & 1 & $1 / 9$ & $1 / 6$ & $1 / 9$ \\
12 & 5 & 7 & 5 & 1 & 4 & 1 & 5 & 6 & 9 & 6 & 9 & 1 & 3 & 6 \\
\hline 13 & $1 / 5$ & $1 / 3$ & $1 / 7$ & $1 / 9$ & $1 / 6$ & $1 / 5$ & $1 / 2$ & $1 / 5$ & $1 / 3$ & $1 / 3$ & 6 & $1 / 3$ & 1 & $1 / 5$ \\
14 & $1 / 6$ & 4 & 1 & $1 / 8$ & $1 / 9$ & 6 & $1 / 9$ & 1 & 7 & 6 & 9 & $1 / 6$ & 5 & 1 \\
\hline SUM & 10.74 & 41.80 & 38.31 & 5.78 & 10.36 & 22.44 & 26.82 & 52.70 & 45.42 & 55.07 & 85.11 & 5.05 & 57.17 & 42.04 \\
\hline
\end{tabular}

Table 4. Normalized matrix for the facility and services indicator.

\begin{tabular}{|c|c|c|c|c|c|c|c|c|c|c|c|c|c|c|c|}
\hline & 1 & 2 & 3 & 4 & 5 & 6 & 7 & 8 & 9 & 10 & 11 & 12 & 13 & 14 & Relative importance \\
\hline 1 & 0.09 & 0.02 & 0.05 & 0.17 & 0.10 & 0.31 & 0.34 & 0.11 & 0.11 & 0.13 & 0.11 & 0.04 & 0.09 & 0.14 & 1.81 \\
\hline 2 & 0.09 & 0.02 & 0.03 & 0.02 & 0.01 & 0.01 & 0.19 & 0.15 & 0.01 & 0.00 & 0.08 & 0.03 & 0.05 & 0.01 & 0.71 \\
\hline 3 & 0.05 & 0.02 & 0.03 & 0.03 & 0.02 & 0.01 & 0.02 & 0.00 & 0.01 & 0.00 & 0.07 & 0.04 & 0.12 & 0.02 & 0.45 \\
\hline 4 & 0.09 & 0.17 & 0.16 & 0.17 & 0.10 & 0.18 & 0.11 & 0.09 & 0.15 & 0.09 & 0.11 & 0.20 & 0.16 & 0.19 & 1.97 \\
\hline 5 & 0.09 & 0.19 & 0.13 & 0.17 & 0.10 & 0.04 & 0.04 & 0.09 & 0.09 & 0.11 & 0.08 & 0.05 & 0.10 & 0.21 & 1.51 \\
\hline 6 & 0.01 & 0.10 & 0.08 & 0.04 & 0.10 & 0.04 & 0.04 & 0.11 & 0.11 & 0.15 & 0.07 & 0.20 & 0.09 & 0.00 & 1.14 \\
\hline 7 & 0.01 & 0.00 & 0.05 & 0.06 & 0.10 & 0.04 & 0.04 & 0.13 & 0.11 & 0.09 & 0.07 & 0.04 & 0.03 & 0.21 & 1.00 \\
\hline 8 & 0.02 & 0.00 & 0.10 & 0.03 & 0.02 & 0.01 & 0.01 & 0.02 & 0.01 & 0.01 & 0.05 & 0.03 & 0.09 & 0.02 & 0.41 \\
\hline 9 & 0.02 & 0.07 & 0.08 & 0.02 & 0.02 & 0.01 & 0.01 & 0.08 & 0.02 & 0.02 & 0.07 & 0.02 & 0.05 & 0.00 & 0.50 \\
\hline 10 & 0.01 & 0.12 & 0.13 & 0.03 & 0.02 & 0.01 & 0.01 & 0.06 & 0.02 & 0.02 & 0.00 & 0.03 & 0.05 & 0.00 & 0.52 \\
\hline 11 & 0.01 & 0.00 & 0.00 & 0.02 & 0.01 & 0.01 & 0.01 & 0.00 & 0.00 & 0.16 & 0.01 & 0.02 & 0.00 & 0.00 & 0.28 \\
\hline 12 & 0.47 & 0.17 & 0.13 & 0.17 & 0.39 & 0.04 & 0.19 & 0.11 & 0.20 & 0.11 & 0.11 & 0.20 & 0.05 & 0.14 & 2.47 \\
\hline 13 & 0.02 & 0.01 & 0.00 & 0.02 & 0.02 & 0.01 & 0.02 & 0.00 & 0.01 & 0.01 & 0.07 & 0.07 & 0.02 & 0.00 & 0.27 \\
\hline 14 & 0.02 & 0.10 & 0.03 & 0.02 & 0.01 & 0.27 & 0.00 & 0.02 & 0.15 & 0.11 & 0.11 & 0.03 & 0.09 & 0.02 & 0.98 \\
\hline
\end{tabular}

Table 5. Index values of urban green parks.

\begin{tabular}{|c|c|c|c|c|c|c|c|c|c|}
\hline \multirow[t]{2}{*}{ Indicator } & \multicolumn{4}{|c|}{ Characteristic } & \multirow{2}{*}{$\begin{array}{l}\text { Indicator } \\
\text { relative } \\
\text { importance }\end{array}$} & \multicolumn{4}{|c|}{ Indicator value $\times$ relative importance } \\
\hline & $\begin{array}{c}\text { Vihara. } \\
\text { park }\end{array}$ & $\begin{array}{c}\text { Diyatha } \\
\text { Uyana }\end{array}$ & $\begin{array}{c}\text { Bellan. } \\
\text { Park }\end{array}$ & $\begin{array}{c}\text { Seetha. } \\
\text { Park }\end{array}$ & & $\begin{array}{c}\text { Vihara. } \\
\text { park }\end{array}$ & $\begin{array}{c}\text { Diyatha } \\
\text { Uyana }\end{array}$ & $\begin{array}{c}\text { Bellan. } \\
\text { Park }\end{array}$ & $\begin{array}{l}\text { Seetha. } \\
\text { Park }\end{array}$ \\
\hline Facility and services & 3.93 & 4.87 & 4.79 & 3.88 & 1.91 & 7.51 & 9.30 & 9.15 & 7.41 \\
\hline Safety and security & 1.71 & 4.52 & 4.22 & 3.84 & 1.68 & 2.87 & 7.59 & 7.09 & 6.45 \\
\hline Location & 4.74 & 4.74 & 4.74 & 2.90 & 1.23 & 5.83 & 5.83 & 5.83 & 3.57 \\
\hline Topography/geography & 2.90 & 2.90 & 2.90 & 4.05 & 0.87 & 2.52 & 2.52 & 2.52 & 3.52 \\
\hline Social and cultural & 3.18 & 0.91 & 2 & 1.91 & 0.23 & 0.73 & 0.21 & 0.46 & 0.44 \\
\hline Ecology & 0.72 & 1.64 & 1.25 & 4.34 & 1.02 & 0.73 & 1.67 & 1.28 & 4.43 \\
\hline Demography & 4.00 & 4.00 & 4.00 & 2.79 & 0.22 & 0.88 & 0.88 & 0.88 & 0.61 \\
\hline Weather and climate & 1.88 & 2.37 & 1.83 & 2.43 & 0.84 & 1.58 & 1.99 & 1.54 & 2.04 \\
\hline \multirow{2}{*}{\multicolumn{5}{|c|}{ Use and accessibility with regard to the urban green parks index values }} & Sum & 22.66 & 30.00 & 28.74 & 28.47 \\
\hline & & & & & Average & 2.83 & 3.75 & 3.59 & 3.56 \\
\hline
\end{tabular}


by the number of factors involved. After that, the individual indicator values were multiplied by the relative importance of indicators to get the final index value.

\section{Results}

The results of the questionnaire survey showed that the Facilities and Services indicator provided was the most significant when selecting a park. The participants gave second priority to Safety and Security measures, while the Ecology, Topographical/Geography and Weather/Climate indicators received lower levels of priority. The park location also played an important role, but the indicators related to social, cultural and demography issues were felt to be of least influence.

Out of the 14 factors of the Facilities and Services indicator, commonly available in urban parks, the highest priority was given to cleanliness and maintenance, including availability of basic facilities such as toilets and water; however presence of sports facilities were also felt to be important. Less priority was given to information boards and the number of maintenance workers. Out of the 10 factors used to determine the indicator value of Safety and Security the participants selected presence of homeless dogs and thefts as the most prominent factors for avoiding a park, while factors, such as park fences, entrance limitations, presence of pets and street children accorded less negative preference.

The study used six factors in the analysis of the importance of location of urban parks,. Here the availability of public transportation making it possible to easily enter into the park was the most prominent factor. Distance to a neighbour park and distance to the main gate from the main road were the least influencing factors. Under the topographical and geographical indicator, the size was the most important, while the shape played no role. The daily average number of visitors was the main factor of the social and cultural indicator, while allocation of areas including water, shade and copses of trees were the most influential factors under the ecology indicator with the biodiversity factors felt to of little importance. The ethnicity of the majority visitor groups was more important compared to gender diversity under the demographic features. Generally, weather and climatic factors are important for the assessment of urban parks. Here, it was found that average rainfall and humidity were the most important factors with the possibility for disaster occurrences also seen as an important factor.

After determining the relative influences of individual factors, we integrated the indicators into a composite index. The relative influence of each indicator was determined using the views of the questionnaire participants. A higher priority was given for the indicators facility and services together with safety and security. Further, the participants choose location and ecology indicators as their second priority, while topography and geography together with weather and climate were ranked lower with social, cultural and demography as the lowest.

According to the results of the study, it can be clearly noticed that the park users are given priority for the Facilities and Services rendered by the park and the safety and security measures in selecting a place for their leisure activities and spending. It, further, clarifies from the results of the case study, which are having higher index values for the parks with more facilities and secured. In the case study, Diyatha Uyana has been ranked as the most popular park compared to other selected parks, since it provides a number of facilities and a safer place for the users. Diyatha Uyana is well famous among the park users, due to its location as well. Though Viharamahadevi park is situated in the heart of the city, park users are reluctant to use it due to safety issues and, specially, due to ecological unsuitability. Further, it can be noticed that though Seethawaka park is little bit far away from Colombo city limits, it has a good index value, since it has better inherent characteristics such as topography and geography, ecology and weather.

\section{Discussion and Conclusions}

The AHP-based study to understand park use from spatial and attribute data presented here was totally dependent on the views of the park users who participated in the survey. In order to get a wellbalanced response, data were collected from different categories of park users from different park locations at different times. This was done to get a variation of views from people who visit urban parks for different purposes. An even better balance could be achieved by extending the questionnaire survey by including a larger number of participants and selecting people representing an even broader spectrum of people. In addition, the study model used could be further enriched by including experts in the disciplines of park management, landscape management, leisure management and health management for the development of future questionnaire surveys. Also the indicators and their respective factors used could be enlarged or modified to fit the model. Although the approach discussed here can be directly applied to assess urban green parks, it cannot be directly applied to assess other types of parks. It would then need to be adapted to other park types by changing the model parameters according to the scenarios at hand. When assessing usage of, and accessibility to, special parks in government and private institutions, e.g., hospital parks, it is clear that user interests and ambitions by managers are different compared to the general public visiting green parks in cities. In such cases, the indicators and factors of the proposed model should be altered asking help of experts and park users through questionnaire surveys and discussions with related parties. In addition, the systematic approach presented here can be further modified to evaluate public parks situated in other cities and countries, introducing additional factors as needed. Importantly, the weighting values of the model may need to be altered to suit the intended set of regular park users and according to experts from various parts of the country (even other countries if need be), since each park scenario would only be known by its regular users.

Finally, it can be concluded that the type of hierarchical processing analysis utilized here is indeed useful for the assessment of public parks with the aim to understand the real situation which may be hidden. We feel that the study provides an improved approach to rank urban green parks using a set of specific indictors. An index-based ranking system is mainly required to enhance an understanding of current park situations with the view to provide a better service for the users. Implementation of a method for park evaluation, further helps park managers to undertake improvements of available features and characteristics where needed. After analyzing the rank of a park, a better understanding about the pros and cons makes possible to provide a good service to the general park users. Though different authors have introduced a number of suggestions to evaluate parks, they have paid attention to a limited number of parameters, while there may be more such variables consistent with the indicators and factors developed here. Hence, the proposed approach provides an innovative technique to assess the usage of, and accessibility to, urban green parks. 


\section{References}

Abubakar IR, Aina YA, 2006. GIS and space syntax: An analysis of accessibility to urban green areas in Doha District of Dammam Metropolitan area, Saudi Arabia. Proceedings of Map Middle East Conference, Dubai, UAE, 2006, March 2629. Available from: http://www.gisdevelopment.net/proceedings/mapmiddleeast/2006/transportation $\% 20$ and $\% 20$ network\%20analysis/mm06tra $79 . \mathrm{htm}$

Abubakr AAA, Pradhan B, 2016. Spatio-temporal prediction of urban expansion using bivariate statistical models: Assessment of the efficacy of evidential belief functions and frequency ratio models. Appl Spat Anal Polic 9:213-31.

Arabi Z, Hatami D, Jadidoleslami M, 2014. Analysis of the pattern of spatial-local distribution of green space: Case study of Mehr city in Iran. Ind J Sci Res 8:197-202.

Berg AEVD, Maas J, Verheij RA, Groenewegen PP, 2010. Green space as a buffer between stressful life events and health. Social Sci Med 2010;70:1203-10.

Caklovic L, Radas S, 2014. Application of potential method to survey analysis. Math Commun 19:397-415.

Cho AH, Poudyal NC, Roberts RK, 2008. Spatial analysis of the amenity value of green open space. Ecol Econ 66:403-16.

Comber A, Brunsdon C, Green E, 2008. Using a GIS-based network analysis to determine urban green space accessibility for different ethnic and religious groups. Landscape Urban Plan 86:103-14.

Dadras M, Shafri HZM, Ahmad N, Pradhan B, Safarpour S, 2015. Spatio-temporal analysis of urban growth from remote sensing data in Bandar Abbas city, Iran. Egypt J Remote Sens Space Sci 18:35-52.

Department of Census and Statistics of Sri Lanka, 2012. The report on mid-year population estimates by district and sex, 20122016. Sri Lanka: Department of Census and Statistics, Ministry of Policy Planning and Economic Affairs, Sri Lanka. Available from: http://www.statistics.gov.lk/

De Ridder K, 2003. BUGS: Benefits of urban green space. Available from: www.eukn.eu/.../11-bugs-benefits-ofurban-green-space.pdf

Fan CC, 1999. The vertical and horizontal expansions of China's city system. Urban Geogr 20:493-515.

Germann-Chiari C, Seeland K, 2004. Are urban green spaces optimally distributed to act as places for social integration? Results of a geographical information system approach for urban forestry research. Forest Policy Econ 6:3-13.

Gilbert OL, 1989. The ecology of urban nabitat. Chapman \& Hall, London, UK.

Handley J, Pauleit S, Slinn P, Lindley S, Baker M, Alan B, Jones $\mathrm{C}, 2003$. Accessible natural green space standards in towns and cities: A review and toolkit for their implementation. Northminster House, Peterborough PE1 1UA. - English nature research reports Report No. 526. Available from: http://publications.naturalengland.org.uk/publication/65021

Hegazy IR, Kaloop MR, 2015. Monitoring urban growth and land use change detection with GIS and remote sensing techniques in Daqahlia governorate, Egypt. Int J Sustain Built Environ 4:117-24.

Herzele AV, Wiedemann T, 2003. A monitoring tool for the provi- sion of accessible and attractive urban green spaces. Landscape Urban Plan 63:109-26.

Jennings V, Larson L, Yun J, 2016. Advancing sustainability through urban green space: Cultural ecosystem services, equity, and social determinants of health. Int J Environ Res Public Health 13:196.

Kaczynski A, Henderson K, 2007. Environmental correlates of physical activity: a review of evidence about parks and recreation. Leisure Sci 29:315-54.

Khalil R, 2014. Quantitative evaluation of distribution and accessibility of urban green spaces (Case study: City of Jeddah). Int J Geomatics Geosci 4:526-35.

Masnavi MR, 2000. The compact city in practice: the new millennium and the new urban paradigm. In: Williams K, Jenks M, Burton EJ, eds. Achieving sustainable urban form. E\&FN Spon Publisher, London/New York, pp 64-73.

McCormack GR, Rock M, Toohey AM, Hignell D, 2010. Characteristics of urban parks associated with park use and physical activity: A review of qualitative research. Health \& Place 16:712-26.

Moirongo BO, 2002. Urban public space patterns; human distribution and the design of sustainable city centers with references to Nairobi CBD. Urban Design Int 7:205-16.

Nicholls S, 2001. Measuring the accessibility and equity of public parks: a case study using GIS. Manag Leisure 6:201-19.

Nonis C, Varghese K, Suresh K, 2007. Investigation of an AHP based multi criteria weighting scheme for GIS routing of cross country pipe line projects, Madras. 24th International Symposium on Automation \& Robotics in Construction (ISARC 2007). Madras, India: Construction Animation Group. Available from: www.irbnet.de/daten/iconda/CIB11234.pdf

Noor NM, Rosni NA, 2013. Determination of spatial factors in measuring urban sprawl in Kuantan using Remote Sensing and GIS. In: Cultural Sustainability in the Built and Natural Environment. AcE-Bs2013Hanoi ASEAN Conference on Environment-Behaviour Studies Hanoi Architectural University, Hanoi, Vietnam, 2013 March 19-22. Procedia Social Behavi Sci 85:502-12.

Pendall R, 1999. Do land use controls cause sprawl? Environ Plan B: Plan Design 26:555-71.

Poyil RP, Misra AK, 2015. Urban agglomeration impact analysis using remote sensing and GIS techniques in Malegaon city, India. Int J Sustain Built Environ 4:136-44.

Rosa DL, 2014. Accessibility to greenspaces: GIS based indicators for sustainable planning in a dense urban context. Ecol Indicators 42:122-34.

Shi L, Shao G, Cui S, Li X, Lin T, Yin K, Zhao J, 2009. Urban three-dimensional expansion and its driving forces - a case study of Shanghai, China. Chin Geogr Sci 19:291-8.

Subasinghe S, Estoque RC, Murayama Y, 2016. Spatiotemporal analysis of urban growth using GIS and remote sensing: a case study of the Colombo Metropolitan Area, Sri Lanka. ISPRS Int J Geo-Inf 5:197.

Uy PD, Nakagoshi N, 2008. Application of land suitability analysis and landscape ecology to urban green space planning in Hanoi, Vietnam. Urban Forestry Urban Green 7:25-40.

Wolch JR, Byrne J, Newell JP, 2014. Urban green space, public health, and environmental justice: The challenge of making cities ‘just green enough'. Landscape Urban Plan 125:234-44. 